\title{
National Liberation Movements AND INCREASING HUMANITARIAN LAW COMPliance
}

\author{
PARKer Abt ${ }^{1}$
}

\section{National Liberation Movements and InCreasing Humanitarian LAW Compliance}

In his book, Just and Unjust Wars, Michael Walzer defends a distinction between justice in making war and justice in fighting war: jus ad bellum and jus in bello, respectively. He argues "It is perfectly possible for a just war to be fought unjustly and for an unjust war to be fought in strict accordance with the rules." Regarding jus in bello, Walzer argues that soldiers should always try to follow jus in bello as codified in international humanitarian law (IHL). A collection of treaties, including the Geneva Conventions and a host of customary international laws, comprise IHL. At the conclusion of his book, Walzer writes, "If we are to aim at [the restraint of war as a military struggle], as we should, we must begin by insisting upon the rules of war and by holding soldiers rigidly to the norms they set. The restraint of war is the beginning of peace."

Increasing compliance with IHL should be a primary concern of international lawmakers. When opponents in war do not expect IHL compliance, a race to the extremes may occur, with each side resorting to their best method for ending the war quickly, regardless of adherence to IHL. ${ }^{4}$ Inherent in Walzer's framework is the notion that states either must trust each other to always follow

${ }^{1}$ Parker Abt is a senior at the University of Pennsylvania studying history. He has done public policy research with the Texas Civil Rights Project and the American Enterprise Institute. After graduation, Parker intends to pursue work in public policy or law. This essay was written for a seminar on the legal rules of war and the philosophy behind them.

2 Michael Walzer, Just and Unjust Wars: A Moral Argument with Historical Illustrations, Fourth Edition (New York: Basic Books, 2006), 21.

3 Ibid., 335.

4 Ibid., 22-24. 
IHL or hold themselves to follow the rules of war regardless of their adversary's decision. In the past few decades, the problem of a race to the extremes has become particularly acute in armed conflicts that feature non-state actors who lack legal status under international law. In Cherif Bassiouni's analysis of the situation:

The high level of victimization indicates an almost generalized practice of noncompliance by both governmental forces and non-state actors engaged in conflicts of a non-international character and internal conflicts. No empirical evidence exists to indicate whether noncompliance by state actors enhances the same by non-state actors, but the emulation factor is assumed to exist. ${ }^{5}$

This paper will attempt to answer the question of how states can induce a larger amount of non-state actors to comply under Walzer's conception of jus in bello. ${ }^{6}$ The paper will argue that one way of inducing compliance is to extend legal status to a wider variety of non-state actors by expanding the definition of a national liberation movement. The paper will proceed by providing some baseline definitions and arguing that terrorists cannot constitute national liberation movements. The paper will then explain that the current method for recognizing national liberation movements lends itself to noncompliance with IHL. In response, it will expand the definition of national liberation movement by counting more groups of individuals as peoples and by recognizing the right to self-determination for certain groups of individuals under Frédéric Mégret's concept of jus insurrectionis, the right to rebel. The paper will justify that expanded definition and demonstrate how the definition will increase recognition of certain non-state actors and thereby increase compliance with IHL. Finally, the paper will address potential challenges to the expanded definition of national liberation movement before concluding with some questions for further research.

5 M. Cherif Bassiouni, "The New Wars and the Crisis of Compliance with the Law of Armed Conflict by Non-State Actors," Journal of Criminal Law and Criminology 98 (2007): 750.

6 In following Walzer's framework, the practicability of this paper's central proposal will hinge on the notion that states will habitually follow the rules of war to which they agree in order to prevent a race to the extremes. 


\section{Definitions}

Under Konstantinos Mastorodimos's definition, "National liberation movements correspond to a category of armed non-state actors who are defined by their objective (self-determination), the quality of their constituency (peoples) and the conduct and/or quality of the opposing government."' This paper will adopt his definition as a starting point and expand upon it. For the purposes of this paper, "peoples" are distinct from national liberation movements in that national liberation movements are the armed groups that represent peoples. For the purposes of this paper, "armed group" will refer to armed non-state actors that are eligible for recognition as a national liberation movement but not have not been recognized as such. Armed groups either are not recognized as the representative of their people or the group of individuals they represent has not been recognized as a people. This paper will only use "national liberation movement" to reference an armed group that has been recognized as a national liberation movement. "Recognition" should be assumed (unless otherwise noted) to mean recognition of a certain designation by resolution of the United Nations (UN) Security Council or by the extant state within which a non-self-governing people exist. ${ }^{8}$

\section{EXCLUDING TERrorists From ELIGIBILITY}

This paper excludes terrorists from both the current definition of national liberation movement and any subsequent expansion of that definition. Excluding terrorists allows states to intensify efforts to subdue them and thereby either hasten their extinction or their commitment to following IHL. If a terrorist group commits to following IHL, they might then be considered a national liberation movement. Failure to exclude terrorists subjects the civilian population of a state to further harm, weakens the credibility of IHL with the public, and provides no meaningful benefit to the state, as terrorist groups will disregard IHL regardless of the state's actions. Furthermore, extending IHL to terrorists would trivialize the rights and responsibilities of soldiers. If states extend IHL to terrorists in every

\footnotetext{
Konstantinos Mastorodimos, "National Liberation Movements: Still a Valid Concept (with Special Reference to International Humanitarian Law)," Oregon Review of International Law 17 (2016): 72.

8 In practice, since individual states do not always follow UN guidance, it would only be necessary for the state or states applying force against the non-self-governing people to give them recognition. However, to create an objective standard for the purposes of this paper, the former definition will be used.
} 
case, then a rogue, law-breaking army could safely disobey IHL. ${ }^{9}$ This would yield one of two results: if both states choose to extend IHL protections to this new class of soldier, they would reduce the responsibilities of soldiers to that of modern terrorists, or, if both states choose not to extend IHL protections, it would cause the race to the extremes that Walzer seeks most to avoid.

Excluding terrorists from the definition of national liberation movement necessarily means grappling with a cliché: one man's terrorist is another man's freedom fighter. States can use an armed group's intentions to differentiate between the two. Terrorists primarily target civilian populations to further a political agenda that does not include the conquering of territory and the governing of individuals. Walzer calls terrorism a "civilian strategy." ${ }^{10}$ He explains: "Terrorism is a way of avoiding engagement with the enemy army...it is so indirect that many soldiers have refused to call it war at all." ${ }^{11}$ National liberation movements and armed groups primarily target militaries to further a political agenda that relies on gaining sovereignty over land to govern the people that live on it.

Distinguishing between terrorists and national liberation movements in this manner would challenge the status quo that allows states to exercise more discretion and categorize ambiguous groups as terrorists. As Mégret writes:

Terrorism has sometimes been used to disqualify any form of non-state actor violence, regardless of the ends pursued. Indeed, this is a favorite ploy of states, many of whom have used the newfound popularity of the designation of groups as terrorist to disqualify not only legitimate political participation, but also what might be described as legitimate political violence. ${ }^{12}$

9 The rogue army is guaranteed to find an opponent that follows IHL in every case. Therefore, the rogue army has nothing to lose by disobeying IHL. This might make them terrorists, but it does not matter since the opponent would not distinguish between terrorists and soldiers to begin with.

10 Walzer, Just and Unjust Wars, 198.

11 Ibid., 197. Of course, neither states nor national liberation movements have proved to be completely successful in avoiding civilian casualties during an armed conflict. This does not ruin the distinction between national liberation movements and terrorist groups, however, because states and national liberation movements will both make good faith efforts to adhere to IHL and judge each other's adherence to the same. Jus in bello is predicated on this sort of understanding; it would be an inconsequential abstraction otherwise.

12 Frédéric Mégret, "Causes Worth Fighting For: Is There A Non-State Jus Ad Bellum?," in 
Balancing between terrorists and national liberation movements is a challenging, subjective task. The needle should move more in the direction of national liberation movements than current practice allows so as to allow more non-state actors to qualify as armed groups. In doing so, one must acknowledge that terrorism as a tactic is not unique to terrorists. Virginia Held argues: "The requirement of legitimate authority should not be thought impossible to meet for non-state groups using violence, including terrorism... Groups using terrorism are not in a category by themselves." 13 States should not disqualify armed groups from the national liberation movement designation. Instead they should classify their terrorist actions as war crimes (a reasonable approach given that the Geneva Convention likens national liberation movements to states on the international stage). The line between terrorist and national liberation movement should be drawn at the point where it is most likely to increase adherence to IHL. One way to accomplish this is to take any group that would refuse to adhere to IHL even if they were given national liberation movement status and exclude them as unlawful combatants.

According to this distinction, Al-Qaeda should be classified clearly as a terrorist group because it targets civilians for a political purpose, the removal of Western soldiers from Somalia and Saudi Arabia, though it has no plans to govern any people or the land on which they live. ${ }^{14}$ For a more nuanced case, one may consider Daesh. If one considers founding of the Islamic State the primary accomplishment of Daesh, then Daesh could be classified as a national liberation movement because it seeks to conquer land for a people it represents for the purpose of living life differently than any extant state would allow. ${ }^{15}$ Though Daesh would qualify as a national liberation movement under Mastorodimos's definition, they will not qualify under this paper's definition because the group does not seek to follow IHL, and is therefore excluded because they are a terrorist group. ${ }^{16}$ Unlike

The Diversity of International Law, ed. Aristotle Constantinides and Nikos Zaikos, 2009, 174.

13 Virginia Held, "Legitimate Authority in Non-State Groups Using Violence," Journal of Social Philosophy 36:2 (May 1, 2005): 188.

14 Tayseer Alouni, “Transcript of Bin Laden's October Interview,” CNN, February 5, 2002, http://edition.cnn.com/2002/WORLD/asiapcf/south/02/05/binladen.transcript/.

15 Mark Berman, "Young Men Left America to Join ISIS. They Ended up Cooking and Cleaning for the Caliphate", Washington Post, February 8, 2018, https://www.washingtonpost.com/news/ post-nation/wp/2018/02/08/young-men-left-america-to-join-isis-they-fled-when-it-didnt-liveup-to-their-expectations/.

16 Jeff McMahan, "Syria Is a Modern-Day Holocaust. We Must Act.," Washington Post, November 30, 2015, https://www.washingtonpost.com/news/in-theory/wp/2015/11/30/syria- 
Mastorodimos's definition, this paper's definition of national liberation movement will rest on its ability to incentivize armed groups to actively seek the label instead of ignore it.

\section{Non-Compliance and the Current Definition of National LIBERATION MOVEMENTS}

\section{History of the Right to Self-Determination in the Twentieth Century}

To whatever extent international law gives national liberation movements the right to use force, ${ }^{17}$ that right comes directly from the right of self-determination that belongs to a "people." The definition of people differs between scholars. Heather Wilson finds that "state practice as well as opinion expressed through the political organs of the UN suggests that [people] is not an ethnic or religious group, but a territorial one." ${ }^{18}$ In other words, people is a word inherently tied to existing states: within a given state, there can only be one people, though many may vie to represent that group. ${ }^{19}$ While this definition of people is not universally held, it is the one that guided international law during the twentieth century.

The right of self-determination, which is essentially the right of peoples to determine the political structures of their state, is a mid-late twentieth century development in international law. Woodrow Wilson popularized the idea to an extent with his 1918 Fourteen Points speech and thereby planted the seeds for its eventual codification into international law. The first concrete step in this process came when Chapter XI of the UN Charter classified certain territories as non-self-governing territories and others as trust and mandated territories. ${ }^{20} \mathrm{This}$ classification was a tacit admission that certain peoples were governed by foreign bodies. The right of these people to self-determination emerged in earnest in

is-a-modern-day-holocaust-we-must-act/; "Syria: 'Deadly Labyrinth' Traps Civilians Trying to Flee Raqqa Battle against Islamic State," Amnesty International, August 24, 2017, https://www. amnesty.org/en/latest/news/2017/08/syria-deadly-labyrinth-traps-civilians-trying-to-flee-raqqa/. 17 Not all scholars are convinced that the right to use force is enshrined in international law. See: Held, "Legitimate Authority in Non-State Groups Using Violence," 179.

18 Heather A. Wilson, International Law and the Use of Force by National Liberation Movements (Oxford: Clarendon Press, 1990), 80.

19 Ibid., 145.

20 Ibid., 88. 
1959 when the UN General Assembly recognized the right of the Algerian people to self-determination. Whereas the General Assembly had originally characterized the Algerian situation as a "threat to peace," one session later they passed a resolution "based solely on the right to self-determination for Algeria." ${ }^{21}$ The charge to codify the right to self-determination was led by Non-Aligned states and generally opposed by Western states, who fought to keep self-determination language out of international treaties and resolutions or to at least temper the language favored by the Non-Aligned states. ${ }^{22}$

Eventually though, the Western nations relented to the demands of the Non-Aligned states. In 1970, the UN unanimously approved the Declaration on Friendly Relations, which stated, "By virtue of the principle of equal rights and self-determination of peoples enshrined in the Charter of the UN, all peoples have the right to freely determine, without external interference, their political status." ${ }^{23}$

Though the right to self-determination eventually became a universally acknowledged rule of international law, the right to use force in obtaining self-determination inched forward at a snail's pace over the mid-twentieth century. Western states could not prevent the Non-Aligned states from having their way when it came to UN resolutions. With the 1949 Geneva Convention, the Western states were more stubborn. For example, they forced the removal of a clause in Article 3 that would have applied IHL to non-international armed conflicts. ${ }^{24}$ The approved language instead named a list of human rights-related responsibilities for all combatants, a list that did not generally change combat calculations. While not an approval of national liberation movements, Article 3 represented a recognition by states that the international community could regulate intrastate conduct during an armed conflict.

In the 1970s, the United States, France, and other states founded by national liberation movements were reluctant to support the legal right to self-determination. Further, the international community almost exclusively applied the right of self-determination to colonial lands during the mid-twentieth century. ${ }^{25}$ This suggests that the few, post-colonial states who recognized a right to self-determination in the 1970 s did so because they wanted to legitimize the recent estab-

21 Ibid., 67.

22 Ibid., 43-46.

23 Quoted in: Wilson, 71.

24 Ibid., 42.

25 Held, "Legitimate Authority in Non-State Groups Using Violence," 177. 
lishment of their own states via self-determination claims. ${ }^{26}$

When revising IHL via the 1977 Additional Protocols to the Geneva Convention, post-colonial states wanted to legitimize their founding liberation movements whereas Western states did not want to give legitimacy to non-state actors in general. The result was a narrow definition of peoples eligible for national liberation movements with little applicability beyond the colonial liberation movements of the mid-twentieth century: "Peoples...fighting against colonial domination and alien occupation and against racist régimes in the exercise of their right of self-determination." ${ }^{27}$

This definition was the result of military accomplishments by the national liberation movements. Their existence and success were immutable realities by 1977 . As such, the definition is a codification of practice, not an example of Western states relenting to the demands of Non-Aligned or post-colonial states. As Bassiouni writes, "Protocol I... came to existence after most [wars of national liberation] had ended and simply codified what had become customary international law." 28

\section{Classifying National Liberation Conflicts as International Armed Conflicts}

For the narrow range of groups that qualified for national liberation movement designation under the First Additional Protocol, the rewards are great. ${ }^{29}$ The First Additional Protocol classifies armed conflicts involving national liberation movements as international armed conflicts, which breaks with the traditional paradigm that all conflicts that involve a non-state actor should be considered non-international. It imputes a state-like characteristic to the peoples that national liberation movements serve, making the national liberation movement akin to an army serving a state.

One can say that the international armed conflict designation is a natu-

26 The need for this legitimacy erodes over time; the legitimacy of the United States government would never appear at risk if it disavowed the legitimacy of governments that came to power in the 1970s through the victories of national liberation movements.

27 "Additional Protocols to the Geneva Conventions," June 8, 1977.

28 Bassiouni, "The New Wars and the Crisis of Compliance with the Law of Armed Conflict by Non-State Actors," 746.

29 For an analysis of the additional rewards, see: Mastorodimos, "National Liberation Movements," 79-81. 
ral, logical evolution of the assertion that peoples are separate from states; if peoples can exist apart from states, then surely armed conflicts between the two are international in nature. Consequently, to believe in the right of self-determination is to believe that conflicts undertaken for exercising the right to self-determination are international in nature. Naturally, states defending against a national liberation movement dislike the characterization of their conflict as international because it implies the state has lost sovereignty over the territory. This helps explain why states are loathe to identify armed groups as national liberation movements. If the state cannot govern the national liberation movement's territory, if, therefore, a superseding set of laws governs the state's relationship with the territory, then, by definition, the state does not have sovereignty over the national liberation movement's territory. ${ }^{30}$

Aside from intangible factors like national pride or international classifications, there are also practical issues at play in labeling national liberation moement armed conflicts as international. Under the Geneva Convention, parties to an international armed conflict have a wide range of responsibilities and protections, features of the jus in bello system. National liberation movements are able to break free from domestic laws, which may prescribe severe punishments for their actions, which the extant state could reasonably classify as treason. If national liberation movement soldiers are captured, the state must treat them as prisoners of war, preventing the state from punishing the soldiers as common criminals. For an extant state, the international armed conflict designation forces them to constrain their actions to jus in bello norms. The state potentially faces consequences at the international level if it fails to follow jus in bello norms, whereas in a non-international armed conflict, the risk is far less because these restrictions do not apply. ${ }^{31}$

Though the First Additional Protocol opened the door for national liberation movements to gain legal status and wartime protections, it ironically cast off other armed groups into legally ambiguous territory. The Protocol set a clear line of demarcation between combatants and civilians and "presumed civilian status in cases of doubt." 32 Armed groups who neither met the narrow definition of national liberation movement nor served as part of a state army could not be granted a legal status. They would be designated civilian soldiers, unlawful combatants, or terror-

30 For a discussion of sovereignty, see: Walzer, Just and Unjust Wars, 89.

31 Dawn Steinhoff, "Talking to the Enemy: State Legitimacy Concerns with Engaging Non-State Armed Groups,” Texas International Law Journal 45 (2009): 315.

32 Steinhoff, 316. 
ists. Classifying armed groups this way increases the likelihood of non-compliance with IHL by these groups and the state fighting them. ${ }^{33}$ Bassiouni writes that, during decolonization, national liberation movements only earned their status after being able to "intensify" their conflicts. ${ }^{34}$ Recognition, therefore, is an accomplishment-driven occurrence; national liberation movements are usually designated as such after they are able to achieve some degree of success on the battlefield. The accomplishment-driven approach here is similar to the way that customary international law classifies internal conflicts. The shortfalls of that system elucidate the similar shortfalls of the current system for defining and recognizing national liberation movements.

\section{The Shortfalls of Accomplishment-Based Recognition}

Wilson identifies three categories of internal conflict recognized by customary international law: rebellion, insurgency, and belligerency. ${ }^{35}$ These categories operate on a sliding scale. Rebellion is the least organized of the three, characterized by riots and terrorist attacks that occur within a state. Rebellions have nothing tethering them to the international system; they fall completely under the purview of domestic law. Non-state actors in a rebellion have no protections under IHL and are subject to the ramifications of the domestic legal system. Because rebellions are contained within a state, there is no reason for the extant state, or any other state, to officially declare a rebellion is occurring, and, as such, rebellion as a designation is not so much a positivist point of law as it is the remainder of a system that defines insurgency and belligerency in relation to the conflict's effect on foreign states. ${ }^{36}$

Insurgency is a controversial term in that scholars disagree on what constitutes an insurgency and on the protections to which insurgents are entitled. Wilson posits "[insurgents] must have sufficient control over territory and sufficient military might for the interests of foreign States to be affected, giving

33 Held, "Legitimate Authority in Non-State Groups Using Violence," 176; Bassiouni, "The New Wars and the Crisis of Compliance with the Law of Armed Conflict by Non-State Actors," 715.

34 Bassiouni, "The New Wars and the Crisis of Compliance with the Law of Armed Conflict by Non-State Actors," 746.

35 Wilson, International Law and the Use of Force by National Liberation Movements, 23.

36 Ibid., 24. 
rise to the necessity of some kind of relations with the insurgents." ${ }^{37}$ The relevant takeaway is that foreign states have the power to designate an internal conflict as an insurgency and that they tend to do so based upon the armed group's ability to rise beyond the crude characteristics of a rebellion and impact international affairs to a meaningful extent, necessitating an informal relationship. To the extent that insurgents make deals with foreign states, the insurgents receive no protections outside of those guaranteed in the particular deals.

Belligerency is the best-defined of the three categories, according to Wilson. Belligerents must control a significant portion of land, be able to sustain a conflict for enough time that it appears to be a war (theoretically, war can only take place between states), and possess enough independence that foreign states negotiate with the belligerents as if they were sovereign. ${ }^{38}$ According to Wilson, "The belligerent power is a lawful subject of international law, sufficiently analogous to a State to be given belligerent rights and be accorded the protection of the humanitarian law of war." ${ }^{9}$ Though belligerents have protections under the law of war, they cannot negotiate binding treaties nor appoint official diplomats. Instead, they may negotiate informal deals with foreign powers, though deals more substantial than insurgents would have the physical ability to keep. For example, Great Britain granted belligerency status to the Confederate States of America during the 1860s and granted their ships safe passage through British ports around the globe for commercial purposes. ${ }^{40}$

Thus, in customary international law, foreign states grant belligerent status out of necessity because the armed group has begun to affect the affairs of the foreign power. Necessity is an analogue of accomplishment. The armed group could only create a necessity through military achievements. The armed group must be able to conquer enough land and inflict sufficient damage on a state that the latter can no longer completely control its space in international relations (hence the reason foreign states must negotiate with the armed group). Since it would not be in the interest of the extant state for foreign states to recognize insurgency or belligerency, one may also conclude that armed groups must gain enough respect or

37 Ibid., 24.

38 Ibid., 25.

39 Ibid., 26.

40 Elizabeth Cobbs Hoffman, “A Dangerous Neutrality,” New York Times Opinionator Blog (blog), May 12, 2011, https://opinionator.blogs.nytimes.com/2011/05/12/a-dangerousneutrality/. 
fear as a fighting force for foreign states to, in their own best interests, disregard the concerns of the extant state.

The practice that armed groups must achieve substantial military accomplishments to earn international recognition is common between the Geneva Convention and customary corners of international law. This practice, the accomplishment-based method of recognition, insufficiently encourages compliance with IHL. Until an armed group achieves sufficient military success to earn belligerent or national liberation movement status, the extant state is likely to relegate the armed group to the status of common criminals or terrorists, which is likely the best method for ensuring the defeat of the armed group. ${ }^{41}$ Dawn Steinhoff believes that, under the current system, "A state is likely to disregard IHL, unless it is in its own interest to apply it." ${ }^{22}$ Bassiouni elaborates on how this chain of events leads to less IHL compliance on the part of armed groups:

Since governments refuse to give belligerent and insurgent groups international legal recognition, the latter may seek to acquire such standing by declaring themselves willing to abide by IHL. By conforming their conduct to IHL, they may seek partial recognition before the international community. In their perceptions, they implicitly become legitimate groups with some semblance of equal status to the governments with which they are in conflict. Precisely to avert such public recognition, however, governments strongly oppose the co-opting of these groups into processes of legitimacy, which in turn removes the incentives for such groups to comply with IHL. ${ }^{43}$

Another deleterious aspect of the accomplishment-based method of recognition is that discouraging armed groups to follow IHL at the beginning of their conflict also discourages them from following it in the later stages of the conflict. One might expect that pressure on an armed group to comply with

41 Mégret, "Causes Worth Fighting For," 176; Held, "Legitimate Authority in Non-State Groups Using Violence," 176.

42 Steinhoff, "Talking to the Enemy," 313.

43 Bassiouni, "The New Wars and the Crisis of Compliance with the Law of Armed Conflict by Non-State Actors," 737. 
international norms would increase as the group approaches statehood. However, in some cases, the victory of armed groups who violate IHL frees them from accountability at the end of the conflict. In victory, the armed groups may negotiate a peace treaty exonerating them for any violations. William Schabas explains two general scenarios under which the war criminals can escape prosecution:

Typically, non-State actors would escape individual criminal responsibility when they were victorious, or when they were able to obtain amnesty in return for a peace agreement. In both situations, the result has been impunity. There is a long tradition of this, and still no shortage of contemporary examples, such as the Belfast Agreement of 1998 and the Peace Agreement between the government of Sierra Leone and the Revolutionary United Front ("RUF") of Sierra Leone of 1999 ("Lomé Peace Agreement") that brought an end to the conflict in Sierra Leone. ${ }^{44}$

Mégret even goes so far as to argue that armed groups who violate IHL may escape prosecution purely on the legitimacy of their movement:

It is interesting to note that following the fall of tyrannical regimes, it is very customary for resistance movements to be immediately absolved of almost allwrongdoingduring the dictatorship. While thismaybesimplyaninstance of 'victor's justice', it is also often premised on a fundamental recognition of the legitimacy of the cause defended, and the heroism of its defenders. ${ }^{45}$

Lastly, armed groups that expect to go unpunished for violating IHL are likely to continue violating it under the simple logic that they should continue the method of fighting that has brought them success. The combination of these factors makes it unlikely that a successful armed group will follow IHL unless it began to do so before its success.

44 William A. Schabas, "Punishment of Non-State Actors in Non-International Armed Conflict Transitional Justice - Northern Ireland and Beyond: Theoretical and International Frameworks," Fordham International Law Journal 26 (2002): 919.

45 Mégret, "Causes Worth Fighting For," 187. 


\section{Expanding Who Qualifies as a National Liberation Movement}

Expanding the Definition of "People" to Allow More Armed Groups under the National Liberation Movement Umbrella

Because of the narrow definition of national liberation movement today, many armed groups are left without legal status. They become anachronisms in a community of states that fears giving the appearance of legitimacy to these armed groups. By extending legal status to them under an expanded definition of national liberation movement, the international community would induce the groups and the states they are battling to follow IHL.

The original justification for national liberation movements was that the rulers of a state did not represent the people of the state. Under the right to self-determination, the people had the ability to have separate representatives: the national liberation movement. Arguably, the national liberation movements were justified in using force so the people could freely exercise their right to self-determination. Given that the goal is to increase the number of groups covered under the national liberation movement umbrella, states should seek to redefine what constitutes a people for purposes of self-determination.

The twentieth-century definition of people used by international bodies in the recognized the existence of only one people within a state. This definition fit decolonization well because the groups who sought national liberation movement status claimed to represent the interests of the entire state and wanted to govern it. The definition of "people" should be expanded to account for other instances when a group's territory is geographically distinct but does not correspond with that of an extant state. The construction of a state alone should not imply its borders encompass one people. As Held concludes, "we might do well to avoid giving automatic legitimacy to existing boundaries and political arrangements, since the origins of all states in force and fraud make the facts of existing power so morally questionable." ${ }^{46}$

One demonstration of Held's point is Iraq, a state whose borders were drawn by a foreign power without much regard for boundaries between the Sunni, Shia, and Kurdish major ethnic groups. Though the groups now govern the state themselves, one could imagine any of the three seeking to create a state of

46 Held, "Legitimate Authority in Non-State Groups Using Violence," 187. 
their own to represent their interests. In the Iraqi case, decades of statehood have not engendered a great deal of nationalism in Iraqi citizens. Iraqis do not feel they are Iraqi as much as they feel they are Sunni, Shia, or Kurdish. These ethnic groups constitute a people in every sense of the word other than that they do not claim to represent the entire state.

If one can recognize that the Kurds, Sunnis, and Shias of Iraq each constitute their own people, then it follows logically that the national liberation movement designation could extend to support secessionists. Wilson even posits that modern international law could support secession, so long as the people is geographically distinct. This caveat is essential to the expanded people definition.

In comparing the people of East Pakistan, a geographically distinct people who received international support for self-determination, to the people of Spain's Basque region, Wilson writes, "The right to self-determination does not mean a right of secession from a self-governing State unless a part of that State has become effectively non-self-governing with respect to the whole." ${ }^{47}$ Recognizing both the practical and legal difficulties posed by asserting the right to peoplehood for a non-geographically distinct group of individuals, states should only remove the restriction on the definition of people that prevents multiple peoples from existing within one state. They should still restrict the definition to generally homogenous groups of individuals across a given geographic area.

To further extend the definition of people, states should recognize that a people can exist across borders. Consider the position of Poland. Over the course of three decades in the late-eighteenth century, surrounding states enveloped different portions of Polish land. Yet, even after the third partition of Poland caused the state to disappear completely from the map, the notion of a Polish person still existed. ${ }^{48}$ Though Poles nominally lived in many states by the year 1800 , they still constituted a people.

To apply this concept to a modern context, the Kurds in Iraq generally identify as a people with the Kurds of Syria and the Kurds of Turkey. ${ }^{49}$ They should have the collective right to self-determination as a people despite their residence

\footnotetext{
47 Wilson, International Law and the Use of Force by National Liberation Movements, 87.

48 See multiple references to Polish soldiers and officers in this contemporary account of Napoleon's withdrawal from Russia: Philippe-Paul de Ségur, Defeat: Napoleon's Russian Campaign, trans. J. David Townsend (New York: NYRB Classics, 2008).

49 "Who Are the Kurds?," BBC News, October 31, 2017, http://www.bbc.com/news/worldmiddle-east-29702440.
} 
over territory that spans three states because they could roughly lay claim to a homogeneously populated area of land. While a Kurdish state is fraught with obstacles on a number of fronts, their right to self-determination should not be one of them. Furthermore, recognition of the Iraqi Peshmerga as the official national liberation movement of the Kurds may make it easier for the people as a whole to rally around this army, one that vows to obey IHL. ${ }^{50}$

\section{The Role of jus insurrectionis in an Expanded National Liberation Movement Definition}

We can expand the number of groups eligible for the national liberation movement designation to groups of people that may not constitute a people in the traditional sense of the word. Mégret developed a system that allows for expanding the definition to a few other groups of individuals.

Mégret makes an argument for international recognition of a right to rebel, what he terms jus insurrectionis. He attempts to draw together different parts of international law to argue that a right to rebel is already implicitly recognized. According to Mégret, "although international law is far from having a clear and explicit position on the issue, it has, through various twists and turns, begun to recognize the fundamental validity of certain causes for a jus insurrectionis." Mégret argues that there are four general scenarios under which a group of individuals has a right to rebel in response: when the rulers are colonizers, when the rulers are occupiers, when the rulers perpetrate atrocities, and when the rulers become tyrannical or totalitarian. Mégret believes that the former two are clearly international in character while the latter two have characteristics that make them mostly domestic in character. ${ }^{52}$

We can use Mégret's jus insurrectionis to further justify the expansion of the national liberation movement designation to groups who represent individuals that would not qualify as a people because he ties jus insurrectionis to characteristics of the state rather than characteristics of the rebels. Therefore, if a rebel group cannot prove it represents a distinct people, it can still qualify as a national liberation movement if it can prove that it represents a group against whom the

\footnotetext{
50 "Peshmerga Forces Fully Abide by the Laws of War: KRG," BasNews, March 30, 2017, http://www.basnews.com/index.php/en/news/kurdistan/339578.

51 Mégret, "Causes Worth Fighting For," 178.

52 Ibid., 180.
} 
state is committing atrocities or acting tyrannically. Representation of a group is still essential to the legitimacy of the armed group, but under jus insurrectionis the group is not defined by what it is, but rather by what is being done to it.

Groups can qualify for self-determination by arguing they are a people. However, furthering the tie of national liberation movements to the doctrine of jus insurrectionis, groups may separately qualify for the right to self-determination under jus insurrectionis because no group should be forced to bear atrocities or tyranny against them. Mégret does well introducing a quote from the famous Dutch jurist Hugo Grotius, "[a tyrannical sovereign] becomes no better than a public enemy, against whom the Nation can and should defend itself. And if he has carried his tyranny to the extreme, why should the life itself of so cruel and faithless an enemy be spared?" 53 While Grotius addresses individual sovereigns, such as kings and princes, his point can be extrapolated to tyrannical governments in general: those who have had to suffer tyranny need not leave the tyrannical government in place.

Mégret does not deeply address the implications of his argument as it relates to the division between international and domestic law. As Mégret admits, "the jus insurrectionis thus fundamentally contributes to the dilution of the traditional distinction between the international and the domestic." 54 When it comes to enforcement, it is important whether jus insurrectionis armed conflicts qualify as international or domestic. If considered international, then the rebels would be able to claim internationally recognized legal status and potentially the protections that come with being a combatant in an international armed conflict. Conversely, if the international community should consider such conflicts domestic, then it would be much harder for the combatants to receive any international protections as IHL aims to protect the sovereignty of states. In other words, a domestic jus insurrectionis would be a set of rules without teeth.

Expanding the definition of national liberation movement to include the groups that would be protected under Mégret's jus insurrectionis would accomplish Mégret's goal of stopping states from labeling all non-state violence as terrorism while also increasing compliance with IHL. It would accomplish this latter objective by giving legal status to a greater number of armed groups. If all states recognized jus insurrectionis, then alleged tyrannical states would only confirm their

4 Ibid., 190. 
tyranny by ignoring it during a rebellion. In other words, neutral states would pressure the alleged tyrannical state to follow jus insurrectionis and IHL in turn. Even when a tyrannical state unjustly refuses to apply jus insurrectionis, there is still an increased likelihood that the rebelling faction would comply with IHL in order to gain national liberation movement recognition by other states. Bassiouni argues that when states recognize the armed groups against whom they are fighting, both sides comply with IHL more frequently:

A number of conflicts have demonstrated that when governments grant some recognition to insurgent groups in order to conduct negotiations, the level of violence is reduced. This has been the case in the conflict in El Salvador and, to some extent, in Colombia. Conversely, when the government of Serbia refused to recognize the Kosovo Liberation Army (KLA), this resulted in the escalation of violence in Kosovo, and ultimately led to NATO intervention...The Popular Movement for the Liberation of Angola (MPLA) in Angola was refused similar recognition, leading to a protraction of that conflict... Thus, recognition serves to reduce violence and enhances the prospects of a political settlement. ${ }^{55}$

Combining Mégret's conception of jus insurrectionis with an expanded definition of "people" will greatly increase the number of armed groups eligible for legal status under the national liberation movement designation. By giving these groups legal recognition, states will increase overall compliance with IHL.

\section{Challenges to an Expanded National Liberation Movement DEFINITION}

\section{The Expanded Definition Values Intentions Too Highly}

In a 2017 speech, former US President George W. Bush said, "Too often we judge other groups by their worst examples while judging ourselves by our best intentions." 56 Though Bush was not discussing the way national liberation

55 Bassiouni, "The New Wars and the Crisis of Compliance with the Law of Armed Conflict by Non-State Actors," 788.

56 Jena McGregor, “The Most Memorable Passage in George W. Bush’s Speech Rebuking 
movements are designated, his words cut right to the heart of the issue: Should states judge groups by their intentions or their accomplishments? Since valuing intentions leads to increased IHL compliance, intentions should therefore be the more heavily weighted.

This opinion flies in the face of some Western nations who refuse to judge armed groups on this basis. In 1973, a US representative to the UN stated, "To classify one kind of conflict as international because of motivation or to accord special treatment to a select class of victims of war because of their motivation is frankly the antithesis of international humanitarian law and totally unacceptable." ${ }^{57}$ One may argue that two unacceptable scenarios may occur if states judge national liberationists solely by their intentions. At the conclusion of hostilities, the extant state, if victorious, would have the obligation to not punish captured combatants due to their prisoner of war status. The state would have to release the combatants, risking the start of a new rebellion altogether. Hostilities would end only if all the liberationists were killed or if they decided to vacate their cause. One may argue that the second of these scenarios is unlikely and the first encourages the state to kill as many liberationists as possible while they still possess combatant status. The state would otherwise not be inclined to do because the state would view the liberationists as members of the state, not enemy combatants, and as such they should not be killed with impunity like enemy combatants can be under IHL.

A proper response to this concern is that no system can reasonably consider intentions completely exclusive of accomplishments or vice-versa. One must always balance the two. Even the current system weighs intentions when designating national liberation movements. The movement must seek to exercise the right of self-determination for its people under the current system. This paper does not suggest the international community should disregard accomplishments. Rather, it argues that weighing intentions more than accomplishments will increase IHL compliance. To prevent the scenario of a recurring liberationist conflict, one must acknowledge that acquiring weapons and building a command structure are two basics that a people's armed group must accomplish before claiming that it is a national liberation movement deserving of jus in bello protections. A state is fully

Trumpism," Washington Post, October 20, 2017, https://www.washingtonpost.com/news/onleadership/wp/2017/10/20/the-most-memorable-passage-in-george-w-bushs-speech-rebukingtrumpism/.

57 Quoted in: Wilson, International Law and the Use of Force by National Liberation Movements, 151. 
within its power to prevent such a movement from emerging using its domestic law. For example, even if there is a non-self-governing people, the state has no obligation to provide the people with weapons. The state could ban the possession of weapons under its domestic law and likewise tighten its borders to prevent any from entering the state illegally. Similarly, with command structures, the state could surely design a law that does not violate international human rights standards but still allows for the imprisonment of individuals long before they can build a working command structure.

\section{Whether States Will Accept the Expanded Definition}

Individual states will not recognize national liberation movements in their territory because it would give them legitimacy and protections. The only cases in which states have recognized national liberation movements are when these movements have already won enough gains or the costs to the civilian population have been so detrimental that it is in the state's interest to grant recognition. The proposed system preserves the lives and mutual respect lost in the interim.

Considering that third-party states are the only ones who will confer the status and benefits of jus insurrectionis on national liberation forces, it is vital to understand what costs and benefits they will incur from doing so. On balance, it appears that the costs of recognizing jus insurrectionis outweigh the benefits. Steinhoff argues that states lose when legal status is given to opposing armed groups:

The political legitimacy that an insurgent group gains from legal recognition can be more harmful to a state than any loss in the state's ability to apply domestic laws. International legal protections may imply that the insurgents earn political rights when they gain legal recognition. For example, once an insurgent member is entitled to POW status, the local population may view him as a warrior. Likewise, states cannot prevent the gain in political or moral legitimacy that a group may achieve through adherence to humanitarian norms. ${ }^{58}$

Evidently, the value a state gains by the national liberation movement

58 Steinhoff, "Talking to the Enemy," 319. 
following IHL does not outweigh the negative consequences. States do not weigh highly the humanitarian benefits that would come from an IHL-compliant opponent such as better medical care for its own wounded soldiers or less terrorist attacks aimed at its civilian population. ${ }^{59}$ Ironically, it is in a state's interest for the national liberation movement to commit terrorism because it delegitimizes them, making them look more like a rogue gang than a state-in-waiting. States calculate that they have more to gain from their opponent's delegitimization than they have to lose from terrorist attacks or war crimes the opponent commits against them.

If history is any indication, states will probably use this cynical calculation to reject an expanded national liberation movement definition. Alternatively, they may grant the status of national liberation movement to a group, only to rescind it once the first civilian dies at the hands of the group. Whether or not the state claims the moral high ground, as in the latter case, the end result will be the same: states will not meaningfully extend national liberation movement status to applicable groups. But they should. Alluding to Walzer's conception of sovereignty, the government of a state may fall with time and with war, but the state itself lives on perpetually so long as there is a people to define it. ${ }^{60}$ Again, this is one reason why international law recognizes conflicts with national liberation movements as international. The essential piece of the state is its people. States should not be willing to trade the lives of its civilians to delegitimize an opponent. If legitimizing the opponent as a national liberation movement would save civilian lives within a state, then that state has a moral obligation to do so.

Another factor worth considering is the interests of third-party states, those where there is neither a national liberation movement fighting the state nor the risk of it happening. These states have the most to gain through the stability of the prevailing world order and would therefore reject the expanded national liberation movement definition on a number of grounds. To begin with, even tacit support of national liberation forces would be a nudge against Geneva Convention Article 2(4), which prohibits the use of force against the territorial integrity of any state. ${ }^{61}$ To protect their positions in the world order, large states have an in interest in extant states keeping their status in the world, particularly when these states are

59 Ibid., 310.

60 To follow up on this allusion, see Walzer's discussion here: Walzer, Just and Unjust Wars,

52-54.

61 Wilson, International Law and the Use of Force by National Liberation Movements, 91. 
also favorable to keeping world stability. ${ }^{62}$ Small, potentially vulnerable states have an immediate interest in denying legitimacy to national liberationists, for they want to discourage national liberation movements from emerging in their own nations. Essentially, most states have an interest in taking an official stance against national liberation forces.

One must concede to these states that the formation of national liberation movements will be more likely if the international community affords them an easier path toward recognition. However, the military tactics used by these movements will become much more predictable than they are now because the movements will be constrained by IHL. Unrecognized, armed groups could pose an inconceivable threat through terrorist attacks or guerrilla tactics or postwar punishments on the extant state that would skirt IHL and possibly end in the worst-case scenario described by Walzer. ${ }^{63}$ Constraining national liberation movements to IHL will benefit states over time because states can use all the time from the moment the expanded definition is passed to prepare for the eventuality of a rebellion. Meanwhile, non-self-governing peoples can only start preparing for battle once they come to the conclusion that there needs to be one. Theoretically, as time goes on the state should become incrementally more prepared for a rebellion and this preparation should be able to defeat national liberation movements that follow IHL.

\section{Conclusion}

In order to avoid Walzer's worst-case, realist war scenario and to arrive at general peace quicker, the international community should attempt to increase compliance with IHL by non-state actors. Though not a panacea to encompass all non-state actors, expanding the definition of national liberation movement to encompass a greater amount of non-state actors who wish to comply with IHL would be a step in the right direction.

In researching, pondering, and writing this paper, one area in particular stood out as a potential topic for further research. It involves the situation where a homogenous group of individuals lives in a heterogeneous community and becomes a distinct minority. Supposing conditions fell so precipitously that the

62 Steinhoff, "Talking to the Enemy," 313.

63 Walzer, Just and Unjust Wars, 22-24. 
minority group rebelled under jus insurrectionis, what land, if any, would they take? Would they rule over the majority group if the government proved tyrannical? Given that states are tied to their people, per Walzer, ${ }^{64}$ would the rebelling group be justified in uprooting the majority from their homes to claim the community for themselves? It would be enlightening to stretch the jus insurrectionis and see where it leads and perhaps one may find more applications of it to IHL and move the world closer to the ultimate goal of universal compliance with IHL. 


\section{REFERENCES}

Alouni, Tayseer. “Transcript of Bin Laden's October Interview.” CNN. Published February 5, 2002. http://edition.cnn.com/2002/WORLD/asiapcf/ south/02/05/binladen.transcript/.

Bassiouni, Mahmoud. C. "The New Wars and the Crisis of Compliance with the Law of Armed Conflict by Non-State Actors." Journal of Criminal Law and Criminology 98 (2007): 711-810.

Berman, Mark. "Young Men Left America to Join ISIS. They Ended Up Cook -ing and Cleaning for the Caliphate." Washington Post. Published February 8, 2018. https:/www.washingtonpost.com/news/post-nation/ wp/2018/02/08/young-men-left-america-to-join-isis-they-fled-when-itdidnt-live-up-to-their-expectations/.

Held, Virginia. "Legitimate Authority in Non-State Groups Using Violence." Journal of Social Philosophy 36.2 (2005): 175-93.

Hoffman, Elizabeth C. “A Dangerous Neutrality.” New York Times. Published May 12, 2011. https://opinionator.blogs.nytimes. com/2011/05/12/a-dangerous-neutrality/.

Mastorodimos, Konstantinos. "National Liberation Movements: Still a Valid Concept (with Special Reference to International Humanitarian Law)." Oregon Review of International Law 17 (2015): 71-110.

McGregor, Jena. “The Most Memorable Passage in George W. Bush's Speech Rebuking Trumpism.” Washington Post. Published October 20, 2017. https:/www.washingtonpost.com/news/on-leadership/wp/2017/10/20/ the-most-memorable-passage-in-george-w-bushs-speech-rebukingtrumpism/.

McMahan, Jeff. “Syria Is a Modern-Day Holocaust. We Must Act.” Washington Post. Published November 30, 2015. https:/www.washingtonpost.com/ news/in-theory/wp/2015/11/30/syria-is-a-modern-day-holocaust-wemust-act/. 
Mégret, Frédéric. "Causes Worth Fighting For: Is There A Non-State Jus Ad Belum?" In The Diversity of International Law. Edited by Aristotle Constantinides and Nikos Zaikos. Leiden, NL: Brill, 2009.

"Peshmerga Forces Fully Abide by the Laws of War: KRG." BasNews. Published March 30, 2017. http://www.basnews.com/index.php/en/news/ kurdistan/339578.

"Protocol Additional to the Geneva Conventions of 12 August 1949, and Relat ing to the Protection of Victims of International Armed Conflicts." International Committee of the Red Cross. Published June 8, 1977.

Schabas, William A. "Punishment of Non-State Actors in Non-International Armed Conflict Transitional Justice-Northern Ireland and Beyond: Theoretical and International Frameworks." Fordham International Law Journal 26 (2002): 907-33.

Ségur, Philippe-Paul de. Defeat: Napoleon's Russian Campaign. Translated by J. David Townsend. New York: NYRB Classics, 2008.

Steinhoff, Dawn. "Talking to the Enemy: State Legitimacy Concerns with Engaging Non-State Armed Groups.” Texas International Law Journal 45 (2009): 297-322.

“Syria: 'Deadly Labyrinth' Traps Civilians Trying to Flee Raqqa Battle Against Islamic State." Amnesty International. Published August 24, 2017.

Walzer, Michael. Just and Unjust Wars: A Moral Argument with Historical Illustrations. Fourth Edition. New York: Basic Books, 2006.

Wilson, Heather A. International Law and the Use of Force by National Liberation Movements. Oxford: Clarendon Press, 1990. 